\title{
Perubahan Tata Guna Lahan di Sub DAS Rembangan - Jember dan Dampaknya Terhadap Laju Erosi
}

\author{
Land Use Changes and Its Impact on Erosion Rates in Rembangan Sub Watershed - Jember Regency \\ Idah Andriyani*, Sri Wahyuningsih, Siska Suryaningtias \\ Program Studi Teknik Pertanian, Fakultas Teknologi Pertanian, Universitas Jember, \\ Jl. Kalimantan No.37, Krajan Timur, Sumbersari, Jember 68121, Indonesia \\ *Email: idahandriyani32@gmail.com
}

Tanggal submisi: 5 Januari 2019; Tanggal penerimaan: 16 April 2019

\begin{abstract}
ABSTRAK
Pemanfaatan lahan yang tidak sesuai dan kurangnya vegetasi penutup tanah dapat meningkatkan potensi erosi. Tujuan dari penelitian ini adalah untuk mengetahui besarnya laju erosi akibat perubahan tata guna lahan pada tahun 2001 dan 2014 di wilayah Sub DAS Rembangan, Jember. Tingkat bahaya erosi ditentukan berdasarkan rumus metode USLE (Universal Soil Loss Equation). Data yang digunakan dalam penelitian ini adalah curah hujan pada tahun 2004 sampai 2014 dari stasiun klimatologi terdekat, erodibilitas tanah berdasarkan pengukuran lapang, DEM (Digital Elevation Model), dan peta tata guna lahan tahun 2001 dan 2014. Hasil penelitian menunjukkan bahwa laju erosi pada daerah penelitian dengan perubahan penggunaan lahan tahun 2001 dan 2014 sebesar 873,1 ton/Ha/tahun dan 881,9 ton/ha/th, laju erosi ini termasuk dalam kondisi sangat berat. Tingkat bahaya erosi akibat perubahan penggunaan lahan dalam kondisi sangat berat mencapai 42,5\% dari luas wilayah keseluruhan. Sehingga, diperlulan tindakan konservasi lahan di wilayah penelitian. Tindakan konservasi lahan dengan tingkat bahaya erosi ringan dapat dikurangi melalui pemilihan dan pengaturan pola tanam, penanaman penutup tanah, dan penggunaan sisa tanaman sebagai mulsa. Pada tingkat bahaya erosi berat direkomendasikan mengembangkan usaha tani tanaman tahunan (tanaman perkebunan atau tanaman industri), sedangkan pada lahan dengan tingkat bahaya erosi sangat berat, maka tidak digunakan untuk lahan pertanian.
\end{abstract}

Kata kunci: Laju erosi; perubahan tata guna lahan; tingkat bahaya erosi; sub DAS Rembangan; USLE

\begin{abstract}
Inappropriate land use and lack of cover crops may increase erosion rates. The purpose of this study was to compare the erosion rates of land use in Rembangan sub-watershed in 2001 and 2014. The erosion rates were calculated using a USLE (Universal Soil Loss Equation) method. The input data used were rainfall from 2004 to 2014, soil erodibility values based on field measurements, DEM (Digital Elevation Model), and land use maps in 2001 and 2014. USLE modeling showed that erosion rates in the study area in 2001 and 2014 were 873.1 tons/ ha/year and 881.9 tons/ha/year, respectively. The erosion rates were classified as a very high level, which covered $42.5 \%$ of the total area. So, land conservation action is vital in the Rembangan Sub-watershed.
\end{abstract}

Keywords: Erosion rates; land use change; Rembangan sub watershed; USLE

DOI: http://doi.org/10.22146/agritech.42424

ISSN 0216-0455 (Print), ISSN 2527-3825 (Online) 


\section{PENDAHULUAN}

Erosi merupakan salah satu penyebab terbesar kerusakan tanah di Indonesia (Sutrisno, dkk., 2013). Erosi merupakan peristiwa pindahnya atau terangkutnya tanah atau bagian-bagian tanah dari suatu tempat ketempat lain oleh media alami. Pada peristiwa erosi, tanah atau bagian-bagian tanah pada suatu tempat terkikis dan terangkut yang kemudian diendapkan ditempat lain. Pengikisan dan pengangkutan tanah tersebut terjadi oleh media alami yaitu air dan angin (Arsyad, 2010). Menurut Tan (1991) dalam Lanyala dkk., (2016) erosi tanah pada ekosistem DAS umumnya terjadi karena pemanfaatan lahan yang tidak mengindahkan kaidah konservasi tanah dan air. Erosi pada suatu lahan menyebabkan hilangnya lapisan atas tanah yang subur.

Menurut UU No. 7 Tahun 2004, daerah aliran sungai (DAS) adalah suatu wilayah daratan yang merupakan satu kesatuan dengan sungai dan anak-anak sungainya, yang berfungsi menampung, menyimpan dan mengalirkan air yang berasal dari curah hujan ke danau atau ke laut. Sub DAS adalah bagian dari DAS yang menerima air hujan dan mengalirkannya melalui anak sungai ke sungai utama. Secara alami kualitas DAS dipengaruhi oleh faktor biofisik pembentuk tanah yaitu relief, topografi, fisiografi, iklim, tanah, air dan vegetasi. Namun penggunaan lahan yang berkaitan erat dengan manusia menyebabkan keseimbangan ekosistem DAS terganggu. Eksploitasi DAS menimbulkan masalahmasalah di antaranya banjir di musim hujan dan kekeringan di musim kemarau, penurunan debit air sungai, erosi, sedimentasi serta longsor (Komaruddin, 2008; Valentina dkk., 2008; Andriyani dkk., 2016).

DAS Bedadung merupakan salah satu sungai terbesar di Kabupaten Jember. DAS tersebut mampu mengairi lahan sawah seluas $93.000 \mathrm{Ha}$ dengan panjang sungai $46.875 \mathrm{~m}$ (Santoso dkk., 2013). Sub DAS Rembangan merupakan bagian dari DAS Bedadung Kabupaten Jember. Secara administrasi sub DAS tersebut mencakup kelurahan Patrang dan Bintoro. Dari hasil observasi lapangan, bahwa pemanfaatan lahan di sub DAS Bedadung mengalami perubahan yang cukup signifikan khususnya berkurangnya vegetasi penutup. Kondisi ini berdampak pada penurunan resapan air permukaan sehingga erosi sedimentasi mengalami peningkatan.

Dengan kondisi DAS Bedadung saat ini, perlu dilakukan penelitian untuk memprediksi besarnya erosi serta tingkat bahaya erosi. Salah satu metode yang dapat digunakan untuk memprediksi besarnya erosi yaitu metode USLE (Universal Soil Loss Equation). Arsyad (2010) menjelaskan, USLE adalah suatu model erosi yang dirancang untuk memprediksi erosi rata-rata jangka panjang dari erosi lembar atau alur di bawah keadaan tertentu, tetapi tidak dapat memprediksi pengendapan dan tidak memperhitungkan hasil sedimen dari erosi pari, tebing sugai, dan dasar sungai. Metode ini mempunyai kelebihan, yaitu proses pengolahan datanya yang sederhana, sehingga mudah dihitung secara manual ataupun menggunakan alat bantu program komputer (Software) (Indrawati, 2000, Valentina dkk., 2008). Tujuan dari penelitian ini adalah untuk membandingkan laju erosi di wilayah Sub DAS Rembangan pada penggunaan lahan tahun 2001 dan 2014.

\section{METODE PENELITIAN}

\section{Lokasi Penelitian}

Penelitian dilakukan pada bulan April sampai Juni 2018 pada Sub DAS Rembangan. Sub DAS Rembangan merupakan bagian dari DAS Bedadung yang secara geografis terletak antara $113^{\circ} 35^{\prime}$ sampai $114^{\circ} 1^{\prime} 17$ BT dan $-7^{\circ} 5^{\prime} 8$ sampai $-8^{\circ} 13^{\prime} 52$ LS. Secara administrasi Sub DAS tersebut mencakup 5 stasiun hujan yaitu stasiun Bintoro, Dam Arjasa, Dam Manggis, Kopang dan Tegal Batu. Sub DAS Rembangan mempunyai luas wilayah $683.541 \mathrm{Ha}$. Penggunaan lahan di wilayah Sub DAS tersebut dominan pada lahan sawah irigasi seluas 206.207 Ha dari seluruh luas wilayah Sub DAS Rembangan. Lokasi Sub DAS Rembangan disajikan pada Gambar 1.

\section{Bahan Alat}

Teknik penentuan lokasi dalam penelitian ini dibagi menjadi dua yaitu, berdasarkan survey dan ijin kepada masyarakat setempat yang dekat dengan lokasi penelitian. Teknik pelaksanaan survey ada dua yaitu pendahuluan dan lapang. Survey pendahuluan dilakukan sebelum survei lapang dengan tujuan menentukan waktu survey lapangan dan jumlah titik sampel pada setiap lokasi penelitian serta jumlah surveyor. Pengambilan sampel berdasarkan survey lapang untuk wilayah Sub DAS yang mudah akses pengambilan sampel menggunakan transportasi.

Alat yang digunakan pada penelitian ini yaitu laptop dilengkapi software GIS ArcMap 10.4.1. Perhitungan laju erosi menggunakan metode Universal Soil Loss Equation (USLE) dengan menggunakan software GIS. Tahapan pengolahan dan perhitungan menggunakan metode USLE dan software GIS. 


\section{Metode Penelitian}

\section{Pengumpulan data dan interpretasi faktor erosi Faktor erosivitas hujan (R)}

Data curah hujan yang digunakan dalam penelitian yaitu data curah hujan dari tahun 2004-2014. Data curah hujan yang digunakan pada Sub DAS Rembangan terdiri dari lima stasiun yaitu stasiun Kopang, Bintoro, Dam Tegal Batu, Dam Arjasa, dan Dam Manggis seperti terlihat pada Gambar 1. Nilai faktor curah hujan dapat ditentkan dengan Persamaan 1 yang dikemukakan oleh Utomo (1994).

$$
R=10,80+4,15 \mathrm{CH}
$$

Keterangan:

$\mathrm{R}=$ Indeks erosivitas bulanan $\mathrm{CH}=$ Curah hujan bulanan $(\mathrm{cm} / \mathrm{th})$

Nilai erosivitas yang terdiri dari 5 stasiun hujan tersebut kemudian diinput pada layer stasiun hujan mengunakan software ArcGIS. Untuk mengelompokkan daerah dengan niali $R$ yang sama dengan mempertimbangkan jarak antar stasiun hujan dilakukan dengan menggunakan metode IDW (Inverse istance Weighting).

\section{Faktor erodibilitas tanah ( $K$ )}

Nilai $\mathrm{K}$ menggambarkan kepekaan jenis tanah terhadap erosi. Semakin tingggi nilai $\mathrm{K}$ maka semakin rentan terhadap erosi. Tinggi rendahnya nilai $\mathrm{K}$ dipengaruhi oleh perbedaan tekstur tanah. Nilai erodibilitas tanah ditentukan berdasarkan pengukuran lapang. Untuk memperoleh nilai K yang sesuai dengan grafik nomograf menurut Wischmeier dan Smith (1978) dalam Arsyad (2010) perlu dilakukan pengambilan sampel tanah di Sub DAS Rembangan. Pengambilan sampel tanah dilakukan dengan tiga bagian yaitu hulu, tengah dan hilir. Pada setiap bagian diambil tiga sampel dengan kedalaman kurang lebih $30 \mathrm{~cm}$. Dimana pengambilan sampel tersebut kemudian dilakukan pengamatan sifat fisik dan kimia tanah.

Metode pengambilan sampel tanah menggunakan tanah terusik dan tak terusik. Kemudian sampel tanah tersebut di analisis di laboratorium. Analisis tersebut dilakukan di Laoratorium Tanah Pusat Penelitian Kopi dan Kakao Indonesia, Kebun Percobaan Kaliwining, Jl. Kebun Renteng Jenggawah, Nogosari, Rambipuji, Jember dan di Laboratorium Tanah Politeknik Negeri Jember. Nilai $\mathrm{K}$ hasil pengukuran lapang dipengaruhi oleh beberapa faktor yaitu tekstur tanah, bahan organik, permaebilitas dan struktur tanah. Jenis tanah di wilayah Sub DAS

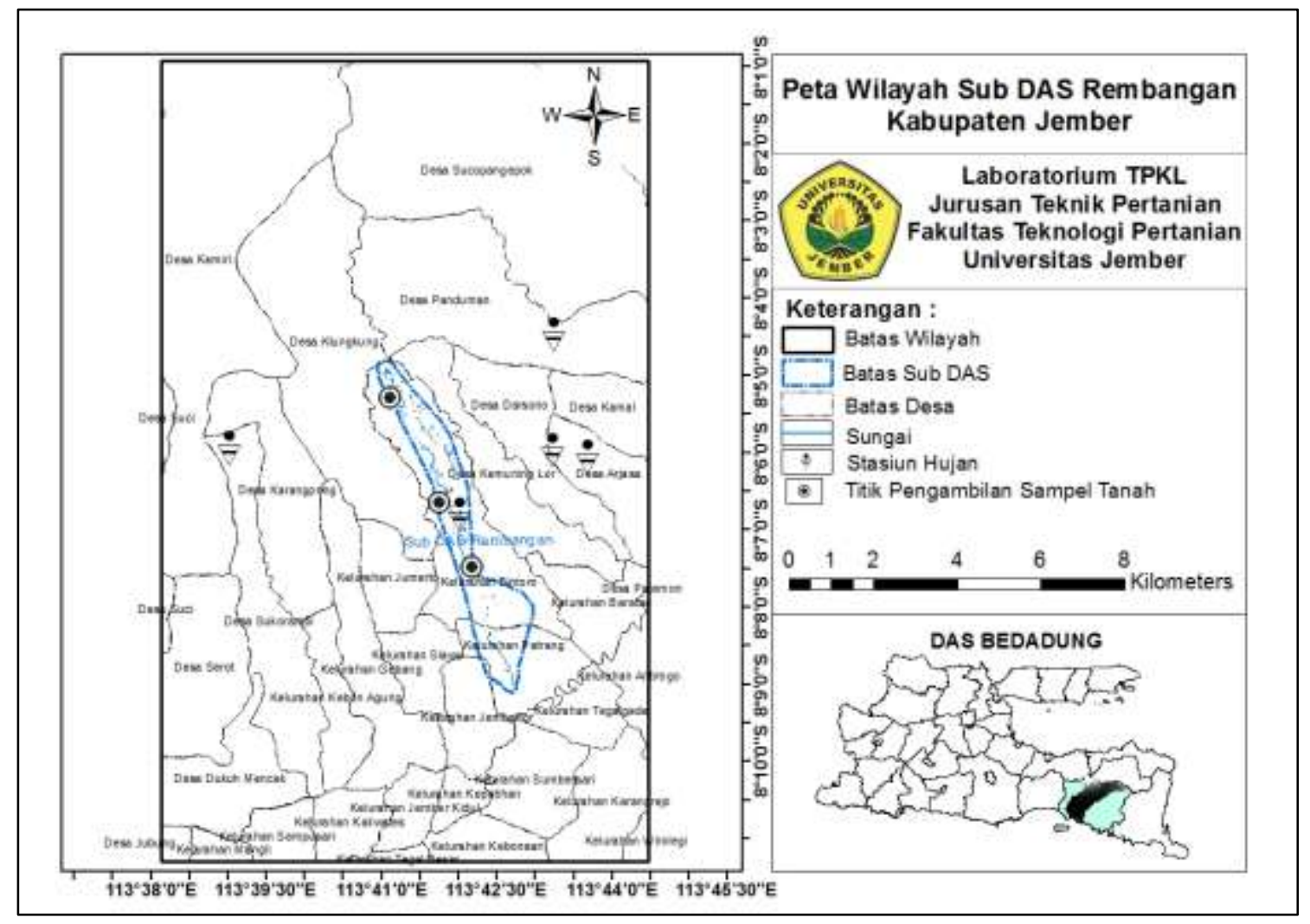

Gambar 1. Lokasi Penelitian Sub DAS Rembangan 
Rembangan terdiri dari dua jenis yaitu tanah latosol dan andosol. Setelah diketahui nilai K, kemudian diinput pada layer $\mathrm{K}$ menggunakan software GIS. Kemudian dilakukan interpolasi IDW (Inverse istance Weighting).

\section{Faktor LS}

Faktor lereng (LS) merupakan rasio antara tanah yang hilang dari suatu petak dengan panjang dan curam lereng tertentu dengan petak baku (tanah gundul, curam lereng $9 \%$, panjang $22 \mathrm{~m}$, dan tanpa usaha pencegahan erosi) yang mempunyai nilai $L S=1$. Analisis spasial LS memanfaatkan data DEM (Digital Elevation Model). Perhitungan faktor LS menggunakan ArcGIS memerlukan data Slope dan arah aliran (Flow Accumulation). Adapun persamaan yang digunakan untuk menghitung faktor LS disajikan pada Persamaan 2.

$$
\mathrm{LS}=\left(\frac{\text { Flow Accumulation } \times \text { Cell Size }}{22.13}\right)^{0.4} \times\left(\frac{\text { Sin Slope }}{0.0896}\right)^{1.3}
$$

Keterangan

$$
\begin{array}{ll}
\text { LS } & =\text { Faktor panjang dan kemiringan lapang (\%) } \\
\text { Flow Accumulation } & =\text { Akumulasi aliran } \\
\text { Slope } & =\text { Kemiringan lereng } \\
\text { Cell Size } & =\text { Ukuran sel }
\end{array}
$$

\section{Faktor CP}

Peta tata guna lahan digunakan untuk mengetahui kondisi pemanfaatan lahan di wilayah penelitian.

Tabel 1. Faktor penggunaan lahan dan pengelolaan tanah (CP)

\begin{tabular}{lll}
\hline No & Penggunaan Lahan & Faktor CP \\
\hline 1 & Pemukiman & 1 \\
2 & Rawa/hutan rawa & 0,01 \\
3 & Empang & 0,001 \\
4 & Pabrik/ bangunan & 1 \\
5 & Bandar udara/pelabuhan & 1 \\
6 & Penggaraman & 1 \\
7 & Sungai & 0,001 \\
8 & Pasir & 1 \\
9 & Danau/bendungan & 0,001 \\
10 & Tanah kosong/padang rumput & 0,02 \\
11 & Semak belukar & 0,1 \\
12 & Sawah irigasi & 0,02 \\
13 & Sawah tadah hujan & 0,05 \\
14 & Hutan & 0,001 \\
15 & Kebun & 0,3 \\
16 & Ladang & 0,28 \\
\hline
\end{tabular}

Sumber : Bappenas (2012)
Adapun peta tata guna lahan dapat ditinjau dari peta Rupa Bumi Indonesia (RBI) pada tahun 2001 dan 2014 skala 1:25.000. Faktor CP dapat ditentukan berdasarkan penelitian di Jawa seperti Tabel 1 menurut Bappenas (2012). Nilai CP kemudian diinputkan pada layer tata guna lahan menggunakan software GIS. Selanjutnya, dikonversi menggunakan tools "polygon to raster" pada software GIS. Faktor penggunaan lahan dapat dilihat pada Tabel 1.

\section{Prediksi laju erosi}

Dari keseluruhan layer yang dihasilkan pada pengumpulan data dan interpretasi faktor erosi kemudian dihitung laju erosi menggunakan metode USLE dengan integrasi software GIS. Perhitungan laju erosi disajikan pada Persamaan 3 (Wischmeier \& Smith, 1978 dalam Arsyad, 2010).

$$
A=R \text {. K.LS.CP }
$$

Keterangan:

$\mathrm{A}=$ jumlah tanah yang tererosi (ton/Ha/tahun);

$\mathrm{R}$ = faktor erosivitas curah hujan tahunan rata-rata ( $\mathrm{cm} /$ tahun);

$\mathrm{K}=$ faktor erodibilitas tanah;

LS = faktor panjang dan kemiringan lereng (\%);

$\mathrm{CP}=$ faktor vegetasi dan pengelolaan konservasi lahan.

\section{HASIL DAN PEMBAHASAN}

\section{Faktor Erosivitas Hujan (R)}

Perhitungan data curah hujan yang digunakan pada Sub DAS Rembangan digunakan untuk mengetahui sebaran nilai faktor $\mathbf{R}$ di wilayah tersebut. Nilai faktor $\mathbf{R}$ dapat dilihat pada Tabel 2 .

Nilai erosivitas yang dihasilkan dari kelima stasiun didominasi oleh stasiun Dam Arjasa dengan nilai erosivitas sebesar $772-812 \mathrm{~cm} /$ tahun dengan luas wilayah seluas $246,96 \mathrm{Ha}$ atau $36,20 \%$. Menurut Asdak (2010), apabila jumlah dan intensitas hujan tinggi maka potensi terjadinya aliran permukaan dan erosi akan tinggi pula. Erosivitas dipengaruhi jatuhnya butirbutir hujan langsung diatas tanah dan sebagian lagi karena aliran air diatas permukaan tanah. Peta sebaran erosivitas hujan disajikan pada Gambar 2.

\section{Faktor Erodibilitas Tanah (K)}

Struktur tanah merupakan susunan saling mengikat partikel-partikel tanah (Darmawijaya, 1990). Permeabilitas tanah merupakan kemampuan tanah untuk meloloskan air didalam tanah baik secara vertikal maupun horizontal (Arsyad, 1989). Hasil nilai erodibilitas tanah berdasarkan pengukuran lapang dapat dilihat pada Tabel 3. 
Tabel 2. Hasil pengolahan data curah hujan Sub DAS Rembangan

\begin{tabular}{llllll}
\hline Desa & Kecamatan & Nama stasiun & Erosivitas hujan (cm/tahun) & Luas (Ha) & Luas (\%) \\
\hline Darsono & Arjasa & Kopang & $0-692$ & 116,82 & 17,12 \\
Bintoro & Patrang & Bintoro & $692-732$ & 79,20 & 11,61 \\
Panduman & Jelbuk & Dam Tegal Batu & $732-772$ & 142,02 & 20,82 \\
Patemon & Pakusari & Dam Arjasa & $772-812$ & 246,96 & 36,20 \\
Sukorambi & Sukorambi & Dam Manggis & $812-852$ & 97,29 & 14,26 \\
\hline
\end{tabular}

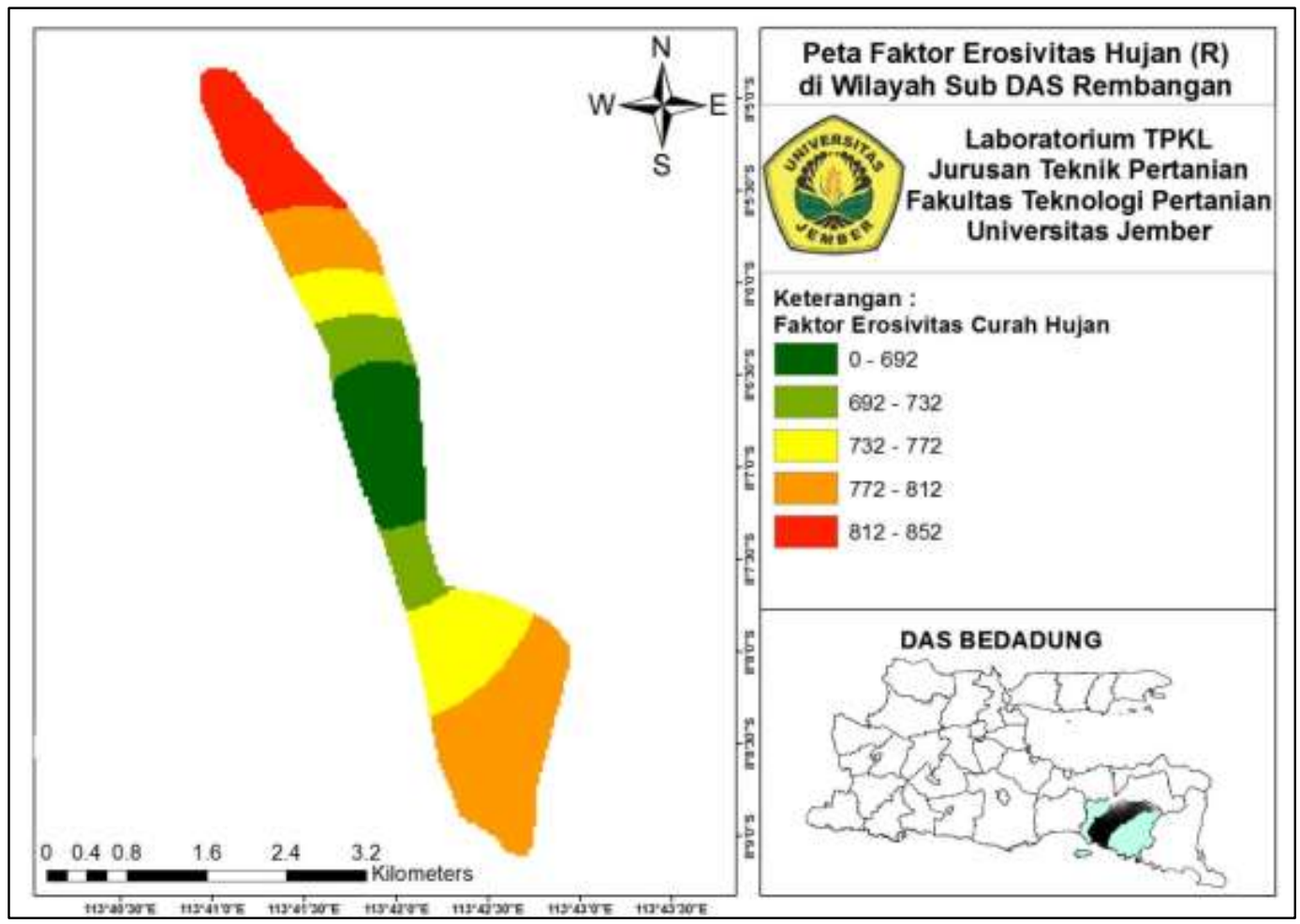

Gambar 2. Peta Faktor Erosivitas (R) Sub DAS Rembangan

Tabel 3. Nilai erodibilitas tanah (K) berdasarkan pengukuran lapang Sub DAS Rembangan

\begin{tabular}{|c|c|c|c|c|c|c|c|}
\hline \multirow[t]{2}{*}{ Sampel } & \multicolumn{3}{|c|}{ Fraksi (\%) } & \multirow{2}{*}{$\begin{array}{c}\text { Bahan } \\
\text { Organik }\end{array}$} & \multirow{2}{*}{ Struktur } & \multirow{2}{*}{ Permaebilitas } & \multirow{2}{*}{$\mathrm{K}$} \\
\hline & Pasir & Debu & Liat & & & & \\
\hline HUTA & 12 & 36 & 52 & 2 & 4 & 6 & 0,41 (Tinggi) \\
\hline TETA & 20 & 42 & 38 & 2 & 4 & 6 & 0,63 (Sangat tinggi) \\
\hline HITA & 19 & 40 & 41 & 2 & 4 & 6 & 0,59 (Sangat tinggi) \\
\hline
\end{tabular}

\section{Keterangan:}

HUTA: Hulu TETA : Tengah HITA : Hilir

Perbedaan hasil nilai K pada Sub DAS Rembangan disebabkan oleh sifat fisik dan kimia tanah, dimana untuk nilai permaebilitas dan bahan organik dapat berubah setiap waktu akibat pengelolaan tata guna lahan. Semakin tinggi kandungan debu maka tanah akan rentan terhadap terjadinya erosi tanah. Tekstur tanah yang sangat halus akan lebih mudah hanyut dibandingkan dengan tekstur tanah yang kasar. Kandungan bahan organik tinggi akan menyebabkan nilai erodibilitas tinggi. Semakin tinggi nilai erodibilitas tanah maka semakin rentan terhadap erosi (Herawati, 2010). Peta faktor $\mathrm{K}$ berdasarkan pengukuran lapang disajikan pada Gambar 3. 


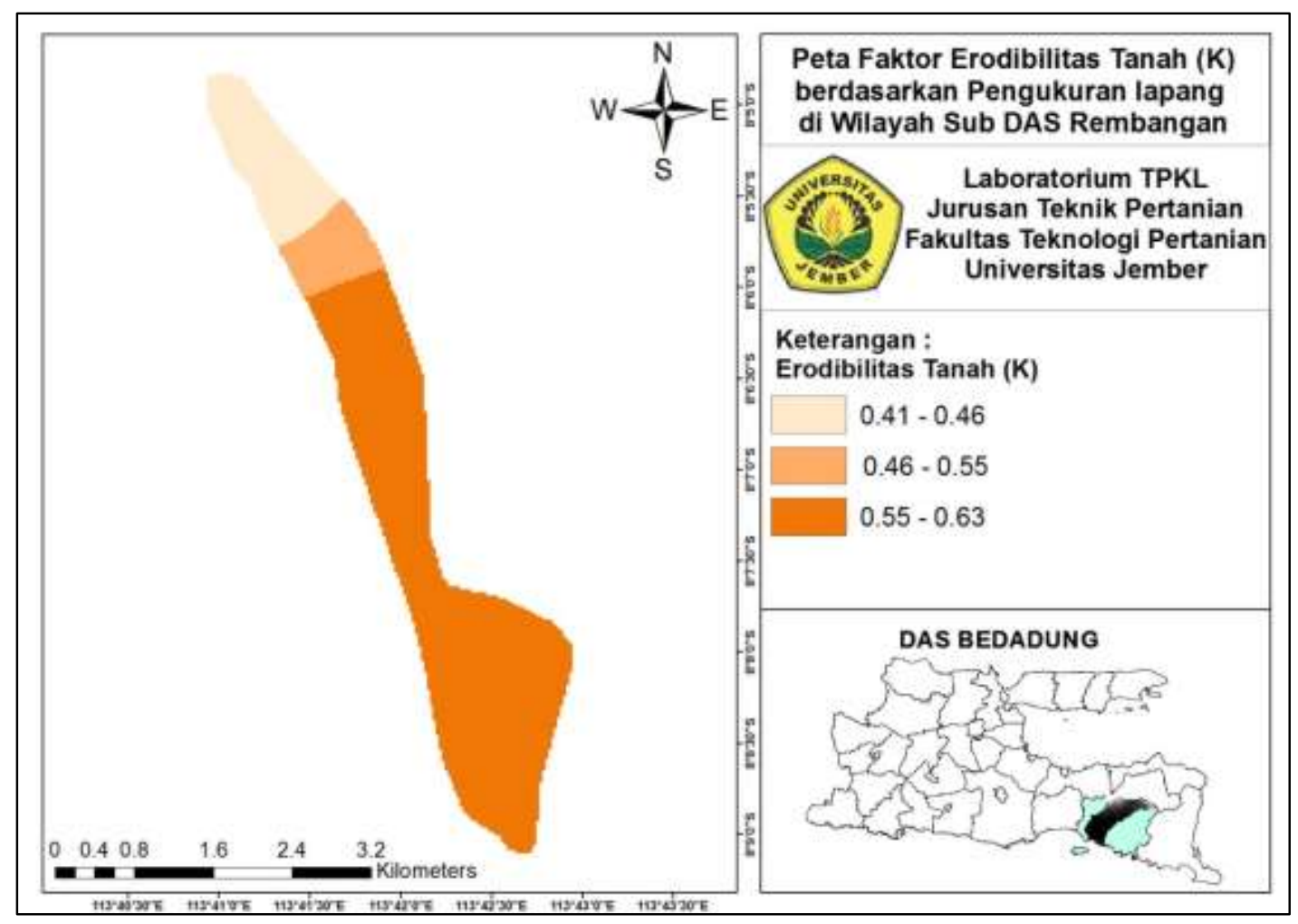

Gambar 3. Peta faktor k berdasarkan pengukuran lapang Sub DAS Rembangan

\section{Faktor Panjang dan Kemiringan Lereng (LS)}

Faktor panjang dan kemiringan lereng dapat mempengaruhi erosi dengan cara semakin panjang suatu lereng maka erosi yang terjadi akan semakin besar. Semakin tinggi nilai LS dengan kondisi yang sangat curam akan mempengaruhi kecepatan aliran permukaan terhadap butir-butir percikan air terhadap daya angkut air yang semakin besar. Untuk menentukan LS diperlukan data Slope dan arah aliran (Flow Accumulation) yang ditentukan dari data DEM (Digital Elevation Model). Nilai hasil perhitungan panjang dan kemiringan lereng dapat dilihat pada Tabel 4.

Tabel 4. Nilai Hasil Perhitungan Panjang dan Kemiringan Lereng

\begin{tabular}{lll}
\hline Klasifikasi LS \% & Luas $(\mathrm{Ha})$ & Luas $(\%)$ \\
\hline $0-1$ & 394,32 & 57,68 \\
$1,1-3$ & 189,26 & 27,69 \\
$3,1-5$ & 73,17 & 10,70 \\
$5,1-9$ & 19,98 & 2,92 \\
$9,1-19$ & 6,85 & 1,00 \\
\hline
\end{tabular}

Tabel 4 menunjukkan bahwa nilai faktor LS diwilayah Sub DAS Rembangan didominasi dengan klasifikasi $0-1 \%$ dengan luas wilayah $394,32 \mathrm{Ha}$ atau $57,68 \%$ dari luas total wilayah Sub DAS Rembangan. Semakin tinggi nilai LS yang diperoleh dari perhitungan dengan kondisi sangat curam akan menyebabkan erosi yang semakin tinggi. Menurut Arsyad (2010) semakin miring suatu lereng, semakin banyak jumlah butirbutir tanah yang terpercik kebagian bawah lereng oleh tumbukan butir-butir hujan. Apabila lereng permukaan tanah menjadi dua kali lebih curam, maka banyaknya erosi per satuan luas menjadi 2,0 sampai 2,5 kali lebih besar. Peta faktor panjang dan kemiringan lereng pada Sub DAS Rembangan dapat disajikan pada Gambar 4.

\section{Faktor Vegetasi Penutup dan Konservasi Tanah (CP)}

Faktor CP yang digunakan wilayah Sub DAS Rembangan berdasarkan peta tata guna lahan tahun 2014. Faktor CP pada Sub DAS Rembangan disajikan pada Tabel 5.

Tabel 5 menunjukkan bahwa terjadi perubahan luasan penggunaan lahan pada tahun 2001 dan 2014 seperti bertambahnya luas kawasan pemukiman, sawah irigasi, dan kebun serta berkurangnya luas kawasan sawah tadah hujan dan ladang. Penggunaan lahan kebun pada lokasi studi didominasi pada tanaman keras seperti kebun kopi, sedangkan penggunaan pada lokasi 


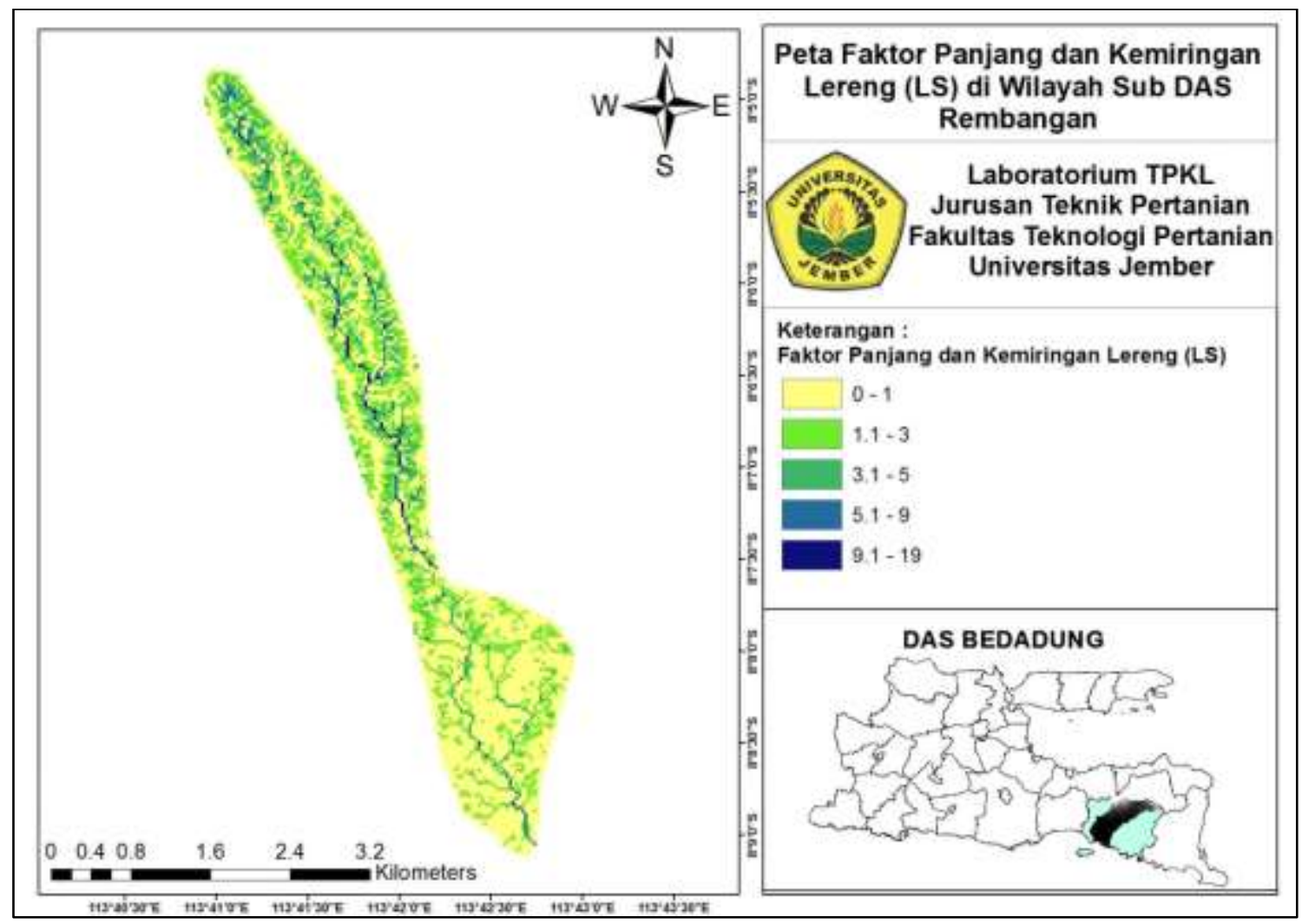

Gambar 4. Peta panjang dan kemiringan lereng Sub DAS Rembangan

studi didominasi pada tanaman keras seperti kebun kopi, sedangkan penggunaan lahan ladang pada lokasi studi didominasi pada tanaman campuran seperti sengon, bambu, mahoni, jagung, pisang. Menurut Arsyad (2010) pengaruh vegetasi terhadap aliran permukaan tanah yaitu sebagai intersepsi air hujan, mengurangi kecepatan aliran permukaan dan kekuatan perusak hujan dan aliran permukaan, pengaruh akar, bahan organik sisa-sisa tumbuhan yang jatuh dipermukaan tanah, kegiatan biologi yang berhubungan dengan pertumbuhan vegetatif dan pengaruhnya terhadap stabilitas struktur porositas tanah, dan transpirasi yang mengakibatkan berkurangnya kandungan air tanah.
Peta faktor CP pada tahun 2001 dan 2014 disajikan pada Gambar 5 dan Gambar 6.

\section{Prediksi Laju Erosi}

Pemodelan USLE menggunakan software GIS dilakukan dengan tool raster calculator. Hasil perhitungan laju erosi tahun 2001 dan 2014 ditunjukkan oleh Tabel 6.

Tabel 6 menunjukkan bahwa terjadi peningkatan tingkat bahaya erosi pada tahun 2001 dan 2014 didominasi pada kondisi sangat ringan seluas $41,4 \%$, sedangkan dalam kondisi berat dan sangat berat seluas

Tabel 5. Faktor CP pada Perubahan Penggunan Lahan Tahun 2001 dan 2014

\begin{tabular}{lllllll}
\hline \multirow{2}{*}{ No } & \multirow{2}{*}{ Penggunaan Lahan } & \multirow{2}{*}{ CP } & \multicolumn{2}{c}{2001} & \multicolumn{2}{c}{2014} \\
\cline { 4 - 7 } & & & Luas (Ha) & Luas (\%) & Luas (Ha) & Luas (\%) \\
\hline 1 & Pemukiman & 1 & 70,741 & 10,365 & 71,564 & 10,486 \\
2 & Sawah irigasi & 0,02 & 202,974 & 29,741 & 206,207 & 30,215 \\
3 & Sawah tadah hujan & 0,05 & 81,943 & 12,007 & 79,586 & 11,661 \\
4 & Kebun & 0,3 & 162,980 & 23,881 & 164,718 & 24,136 \\
5 & Ladang & 0,28 & 163,830 & 24,006 & 161,467 & 23,659 \\
\hline
\end{tabular}




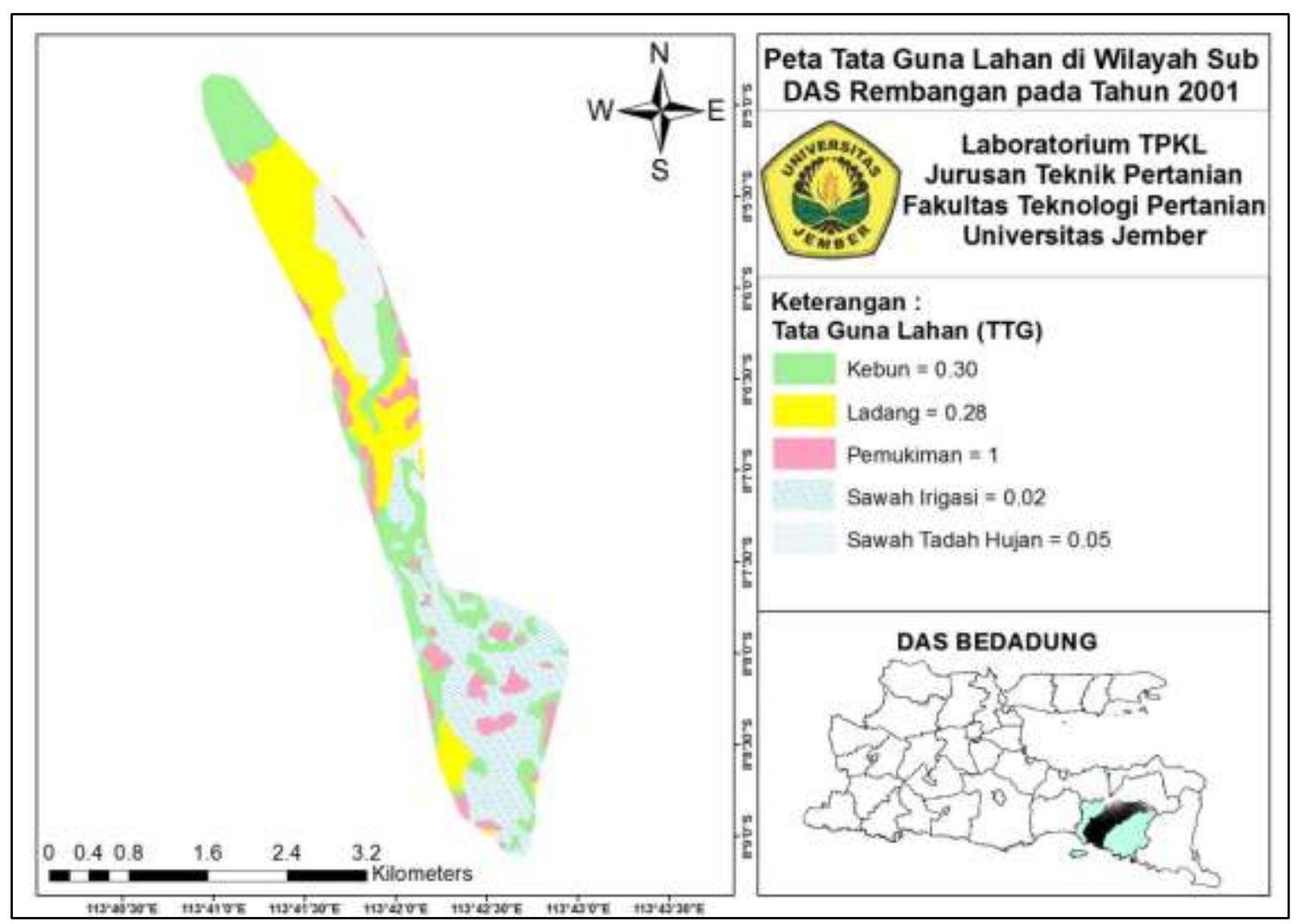

Gambar 5. Peta tata guna lahan Sub DAS Rembangan pada tahun 2001

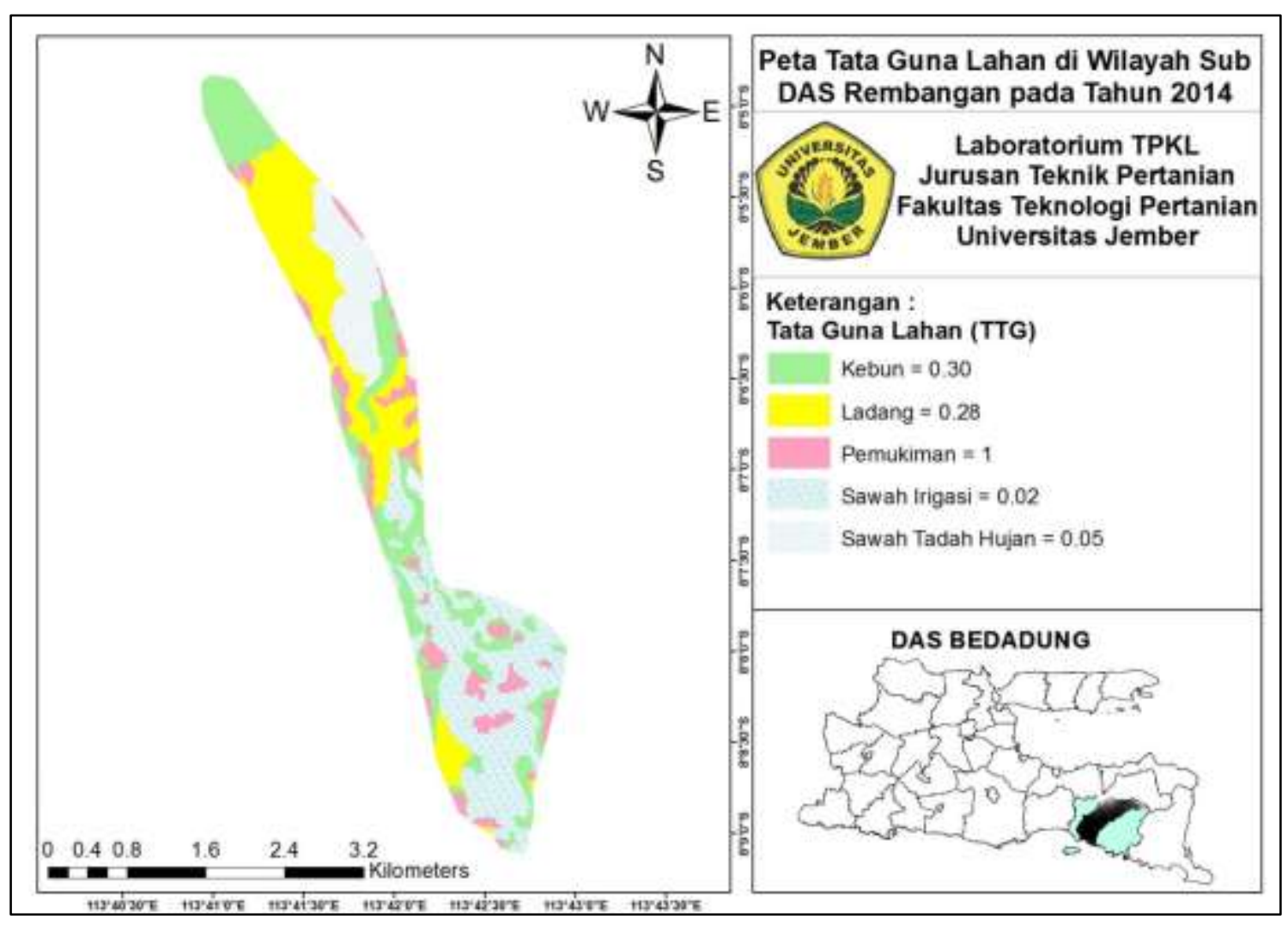

Gambar 6. Peta tata guna lahan Sub DAS Rembangan pada tahun 2014 
Tabel 6. Laju dan tingkat bahaya erosi Sub DAS Rembangan

\begin{tabular}{llcccc}
\hline \multirow{2}{*}{ TBE (Ton/Ha/Th) } & Kondisi & \multicolumn{2}{c}{ Luas (\%) } & \multicolumn{2}{c}{ Laju Erosi (ton/Ha/th) } \\
& & 2001 & 2014 & 2001 & 2014 \\
\hline $0-15$ & Sangat Ringan & 41,4 & 41,4 & 0 & 0 \\
$15-60$ & Ringan & 7,0 & 7,2 & 36,3 & 36,1 \\
$60-180$ & Sedang & 9,0 & 9,0 & 101,8 & 102,1 \\
$180-480$ & Berat & 7,9 & 7,8 & 304,6 & 303,1 \\
$>480$ & Sangat Berat & 34,6 & 34,6 & 2418,5 & 2448,3 \\
\hline Rerata laju erosi (ton/Ha/th) & 873,1 & 881,9 & & & \\
\hline
\end{tabular}

\section{2,5\% sehingga perlu dilakukan konservasi lahan.}

Secara umum Sub DAS Rembangan mempunyai tingkat bahaya erosi sangat berat, akan tetapi untuk mencegah meningkatnya tingkat bahaya erosi sebagai dampak perubahan penggunaan lahan, perlu dilakukan tindakan konservasi lahan. Untuk mempertimbangkan tingkat bahaya erosi sangat ringan, vegetasi yang ada di wilayah Sub DAS harus dipertahankan serta menggunakan sisa-sisa tanaman sebagai mulsa. Tingkat bahaya erosi sedang perlu dilakukan pemilihan dan pengaturan pola tanam serta menggunakan teras bangku dan guludan. Tingkat bahaya erosi berat perlu dilakukan reboisasi atau penanaman tanaman tahunan.
Menurut Lanyal dkk., (2016) lahan dengan tingkat bahaya erosi ringan dapat dikurangi melalui pemilihan dan pengaturan pola tanam, penanaman penutup tanah, dan penggunaan sisa tanaman sebagai mulsa, pada tingkat bahaya erosi berat dengan mengembangkan usaha tani tanaman tahunan (tanaman perkebunan atau tanaman industri), sedangkan pada lahan dengan tingkat bahaya erosi sangat berat tidak digunakan untuk lahan pertanian. Selain penggunaan lahan yang mempengaruhi tingkat bahaya erosi faktor lainnya juga berpengaruh seperti faktor erosivitas hujan, nilai erodibilitas tanah, panjang dan kemiringan lereng. Peta tingkat bahaya erosi berdasarkan pengukuran

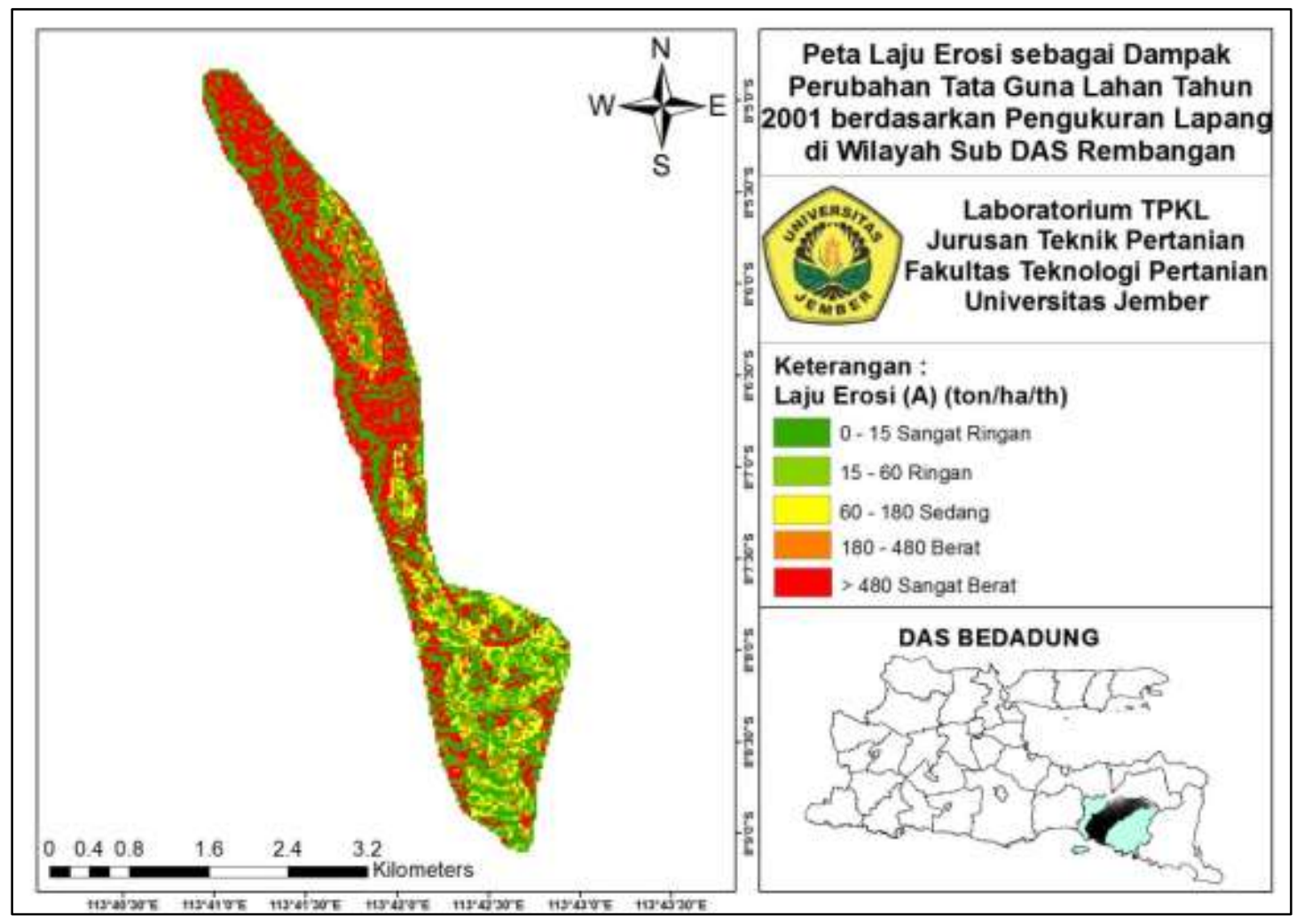

Gambar 7. Peta laju erosi sebagai dampak perubahan tata guna lahan tahun 2001 berdasarkan pengukuran lapang di wilayah Sub DAS Rembangan 


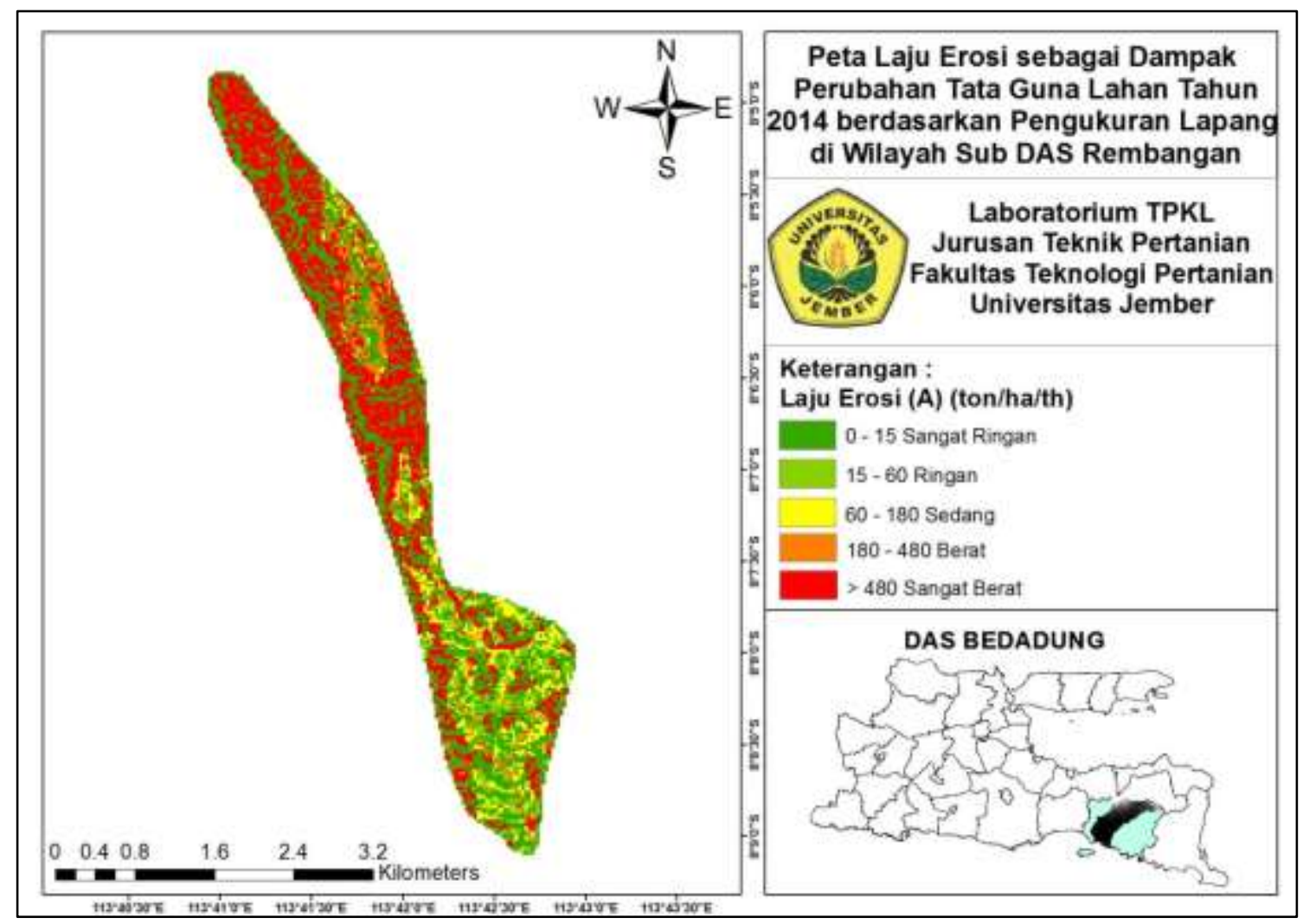

Gambar 8. Peta laju erosi sebagai dampak perubahan tata guna lahan tahun 2014 berdasarkan pengukuran lapang di wilaya

lapang dan peta jenis tanah pada Sub DAS Rembangan disajikan pada Gambar 7 dan Gambar 8.

\section{KESIMPULAN}

Berdasarkan pembahasan yang telah dijelaskan di atas maka dapat disimpulkan bahwa laju erosi pada tahun 2001 dan 2014 di wilayah Sub DAS Rembangan dengan kondisi sangat berat sebesar 873,1 ton/ $\mathrm{Ha} /$ tahun dan 881,9 ton/Ha/tahun. Oleh sebab itu, perlu dilakukan tindakan konservasi lahan untuk mengurangi tingkat bahaya erosi. Tindakan konservasi yang dipertimbangkan untuk wilayah Sub DAS Rembangan adalah mempertahankan vegetasi yang ada, penggunaan sisa tanaman sebagai mulsa, penggunaan teras bangku, guludan, dan reboisasi.

\section{UCAPAN TERIMA KASIH}

Ucapan terima kasih terutama ditujukan kepada pemberi dana penelitian atau donatur (Hibah Pendukung IDB Bacth ke II Universitas Jember Tahun 2018) dan kepada pihak-pihak yang membantu pelaksanaan penelitian.

\section{KONFLIK KEPENTINGAN}

Penulis menyatakan bahwa artikel ini asli hasil penelitian para penulis, hanya dipublikasikan pada jurnal ini, dan tidak ada konflik kepentingan.

\section{DAFTAR PUSTAKA}

Andriyani, I., Jourdain, D., Lidon, B., Soni, P., and Kartiwa, B. (2017). Upland Farming System Erosion Yields and Their Constraints to Change for Sustainable Agricultural Conservation Practices: A Case Study of Land Use and Land Cover (LULC) Change in Indonesia. Land Degrad. Develop., 28: 421- 430. doi: 10.1002/ldr.2598.

Arsyad, S. (1989). Konservasi Tanah dan Air. IPB Press: Bogor. Arsyad, S. (2010). Konservasi Tanah dan Air. IPB Press: Bogor. Bappenas. (2012). Analisis Perubahan Penggunaan lahan dan Ekosismtes DAS Dalam Menunjang Ketahanan Air Dan Ketahan Pangan (Studi Kasus DAS Berantas). ebook. 
Jakarta : Direktorat Kehutanan dan Konservasi Sumber Daya Air. https://anzdoc.com/queue/analisa-perubahanpenggunaan-lahan-di-ekosistem-das-dalam-me.html [24 September 2018].

Darmawijaya, M. I. (1990). Klasifikasi Tanah: Dasar Teori bagi Peneliti Tanah dan Pelaksana Pertanian di Indonesia. UGM Press: Yogyakarta.

Herawati, T. (2010). Analisis Spasial Tingkat Bahaya Erosi di Wilayah DAS Cisadane Kabupaten Bogor. Bogor: Jurnal Penelitian Pengembangan Hutan dan Konservasi Alam. http://ejournal.forda-mof.org/ejournal-litbang/index. php/JPHKA/article/view/1253 [24 September 2018].

Indrawati. (2000). Kajian Erosi DAS Citarum Hulu terhadap Sedimentasi Waduk Saguling, Jawa Barat. Skripsi. Jurusan Geofisika dan Meteorologi. Fakultas Matematika dan Ilmu Pengetahuan Alam. IPB. Bogor.

Lanyala, A. A. A., Hasanah, U., \& Ramlan. (2016). Prediksi Laju Erosi pada Penggunaan Lahan berbeda di Daerah Aliran Sungai (DAS) Kawatuna Propinsi Sulawesi Tengah. Agrotekbis 4(6), 633-641.

Mahmud M., Joko H., Susanto, S. (2009). Penilaian Status Daerah Aliran Sungai (Studi Kasus Sub Das Serang) AGRITECH, Vol. 29, No. 4. https://doi.org/10.22146/ agritech.9697
Santoso, B., Hendrijanto, K., Rahmawati, A., Jannah, R., dan Tyas, M. R. (2013). Model Intervensi Pengelolaan Daerah Aliran Sungai (DAS) (Community Based Action Research pada Masyarakat di Daerah Aliran Sungai Bedadung Kabupaten Jember). Jember: Program Studi Sosiologi FISIP Universias Jember.

Sutrisno, N., Heryani, N. (2013). Teknologi Konservasi Tanah dan Air untuk mencegah Degradasi Lahan Pertanian Berlereng. J. Litbang Pert. Vol. 32 No. 3 September 2013: $122-130$

Undang-undang Nomor 7. (2004). Undang-undang Nomor 7 Tahun 2004 tenang Sumberdaya Air. Pemerintah Republik Indonesia: Jakarta.

Utomo, W.H., (1994). Erosi dan Konservasi Tanah. IKIP. Malang.

Valentina, F. Agus, BR. Alambanc A. Boosanerd J.P. BricqueteV. Chaplotf T. de Guzmang A. de Rouwa J.L. Janeauf D. Orangeh K. Phachomphonhi Do Duy Phaih P. Podwojewskif O. Ribolzii N. Silveraj K. Subagyonob J.P. Thiébauxi Tran Duc Toanh T.V adarib (2008). Runoff and sediment losses from 27 upland catchments in Southeast Asia: Impact of rapid land use changes and conservation practices. Agriculture, Ecosystems \& Environment Volume 128, Issue 4, Pages 225-238. https://doi.org/10.1016/j.agee.2008.06.004 